\title{
Pengaruh pemberian ekstrak jintan hitam (Nigella sativa) terhadap kualitas spermatozoa tikus wistar (Rattus norvegicus) yang terpapar asap rokok
}

\author{
${ }^{1}$ Irene M. A. Rumampuk \\ ${ }^{2}$ Lydia Tendean \\ ${ }^{2}$ Grace L. A. Turalaki
}

\author{
${ }^{1}$ Kandidat Skripsi Fakultas Kedokteran Universitas Sam Ratulangi \\ ${ }^{2}$ Departemen Biologi Fakultas Kedokteran Universitas Sam Ratulangi \\ Email: irene.rumampuk@yahoo.co.id
}

\begin{abstract}
Continuous exposure to cigarette smoke has been reported as the number one cause of infertility in men. Cigarette smoke increases the production of reactive oxygen species (ROS) thereby causing infertility in men. Nigella sativa contains antioxidant that may decrease ROS level in hope to improve infertility. This 50 days study is conducted to see the effect of Nigella sativa extract to the sperm quality of nine wistar rats that have been exposed by cigarette smoke. The rats were divided into three groups of three: the control group and the group treated with Nigella sativa administered orally at the dose of $200 \mathrm{mg} \mathrm{kg}$ body weight and $400 \mathrm{mg} / \mathrm{kg}$ body weight. Sperm quality was observed by overlooking at the concentration, motility, and morphology of each group. The mean data of each group was obtained and tested for significance using Independent Samples T-Test. This study found the comparison of both motility $(p=0,006)$ and morphology $(p=0,000)$ between control group and the group with the dose of $200 \mathrm{mg} / \mathrm{kg}$ body weight to be significant, as well as the comparison of motility $(p=0,001)$ and morphology $(p=0,000)$ between the control group and the group with the dose of $400 \mathrm{mg} / \mathrm{kg}$ body weight.
\end{abstract}

Keywords: sperm quality, nigella sativa, smoking, cigarette

\begin{abstract}
Abstrak: Paparan secara terus menerus terhadap asap rokok merupakan penyebab infertilitas utama pada pria. Asap rokok dapat meningkatkan Reactive oxygen species (ROS) yang selanjutnya dapat menyebabkan infertilitas. Nigella sativa mengandung antioksidan yang dapat menunrunkan jumlah ROS dan diharapkan untuk dapat mengkoreksi infertilitas. Penelitian yang dilaksanakan selama 50 hari ini bertujuan untuk melihat pengaruh dari ekstrak Nigella sativa terhadap kualitas spermatozoa sembilan tikus wistar yang terpapar asap rokok. Tikus dibagi menjadi tiga kelompok masing-masing terdiri atas tiga tikus; terdapat kelompok kontrol dan kelompok yang diberi ekstrak Nigella sativa dengan dosis $200 \mathrm{mg} / \mathrm{kg}$ BB dan 400 $\mathrm{mg} / \mathrm{kg}$ BB. Kualitas spermatozoa dinilai berdasarkan konsentrasi, motilitas dan morfologi dari masing-masing kelompok perlakuan. Data rerata dari tiap kelompok perlakuan diambil dan di diuji signifikans menggunakan uji T-independen. Penelitian ini mendapati perbandingan baik motilitas $(\mathrm{p}=0,006)$ ataupun morfologi $(\mathrm{p}=0,000)$ dari kelompok kontrol dan perlakuan dengan dosis $200 \mathrm{mg} / \mathrm{kg}$ BB dibilang signifikan, sama halnya dengan perbandingan antara motilitas $(0,001)$ dan morfologi $(0,000)$ dari kelompok kontrol dan perlakuan dengan dosis $400 \mathrm{mg} / \mathrm{kg}$ BB.
\end{abstract}

Kata kunci: kualitas sperma, jintan hitam, rokok

Kebiasaan merokok diketahui berhubungan dengan berbagai penyakit yang membahayakan manusia. ${ }^{1}$ Pada tahun 2011

kebiasaan merokok menyebabkan sekitar 5 
juta kematian per tahun dan diperkirakan akan menyebabkan sekitar 8 juta kematian per tahun sampai tahun 2030. ${ }^{2}$ Kebiasaan merokok dilaporkan menyebabkan juga kerusakan pada morfologi, motilitas dan konsentrasi spermatozoa, selain itu dapat memperlambat proses terjadinya konsepsi sehingga kebiasan merokok disimpulkan sebagai salah satu penyebab utama dari infertilitas. $^{1}$

Bidang kesehatan reproduksi mulai memfokuskan perhatian terhadap penelitian tentang Reactive Oxygen Species (ROS). Sperma sangat sensitif terhadap kerusakan yang disebabkan oleh ROS seperti anion superoksida, hidrogen peroksida, dan hidroksil radikal yang menyebabkan kerusakan pada sel membran sehingga dapat memperburuk fungsi sperma. Produksi ROS akan meningkat dengan adanya pengaruh lingkungan dan faktor gaya hidup seperti polusi udara dan merokok. 4 .

Menurut laporan World Health Organization (WHO) obat tradisional digunakan sebagai pengobatan primer bagi $70-80 \%$ populasi manusia. Ada berbagai macam tanaman yang digunakan sebagai tanaman obat diantaranya jintan hitam (Nigella sativa) yang merupakan tanaman dari Famili Rannculaceae tumbuh endemik pada beberapa tempat di Timur Tengah dan negara-negara di Mediterania Selatan. Tanaman ini sering digunakan oleh masyarakat sebagai anti-inflamasi, antikanker, antiparasit, antibakteri, dan antioksidan . ${ }^{5}$

Unsur-unsur kimia dalam jintan hitam (Nigella sativa) antara lain: air, protein, lemak, kalsium, vitamin A, vitamin B2, asam askorbat, niasin, fiber, dan abu. Selain unsur-unsur kimia di atas, jintan hitam (Nigella sativa) mengandung ekstrak esensial, 15 asam amino (alanin, arginin, isoleusin, lisin, triptofan, tirosin, treonin, asparagin, sistin, glisin, asam glutamat, metionin, dan prolin), zat besi, natrium, kalium, tiamin, riboflavin, piridoksin, niasin, tembaga, dan zinc. Kandungan utama jintan hitam (Nigella sativa) adalah Thymoquinone (TQ), Dithymoquinone
(DTQ), Thymohidroquinone (THQ), dan Thymol (THY) yang berperan sebagai antioksidan. Jintan hitam (Nigella sativa) juga mengandung nigellon dan glutathion yang berfungsi sebagai protektor atau melindungi tubuh dari berbagai bahaya zatzat asing (xenobiotics). ${ }^{3}$

Tujuan dari penelitian ini adalah untuk melihat efek pemberian ekstrak jintan hitam (Nigella sativa) terhadap kualitas spermatozoa tikus wistar (Rattus norvegicus) yang terpapar asap rokok.

\section{METODE PENELITIAN}

Penelitian ini menggunakan metode eksperimental analitik dengan pendekatan post-test only control group design. Penelitian dilaksanakan di Bagian Biologi Fakultas Kedokteran Universitas Sam Ratulangi Manado pada bulan Oktober 2015 sampai Januari 2016. Populasi penelitian ini adalah tikus wistar (Rattus norvegius) murni. Sampel penelitian ini adalah 9 tikus wistar jantan berumur sekitar 8 bulan, dengan berat badan $200-250$ gram, kondisi sehat, dan tidak terdapat kelainan anatomis. Seluruh tikus dibagi atas tiga kelompok perlakuan yakni kelompok kontrol $\left(\mathrm{P}_{0}\right)$, dan dua kelompok perlakuan yakni $\left(\mathrm{P}_{1}\right)$ dan $\left(\mathrm{P}_{2}\right)$ yang masingmasing diberi ekstrak jintan hitam (Nigella sativa) dengan dosis $200 \mathrm{mg} / \mathrm{kgBB}$ dan 400 $\mathrm{mg} / \mathrm{kgBB}$ selama pemaparan asap rokok. Pemaparan asap rokok dilakukan setiap hari selama 50 hari. Pada hari ke-51 semua tikus dikorbankan. Tikus diterminasi kemudian dibedah untuk mengambil potongan testis yang berisi sperma tikus. Sperma yang diambil kemudian dinilai konsentrasi, motilitias, dan morfologinya. Data yang diperoleh kemudian dianalisis secara statistik untuk melihat perbandingan antar kelompok perlakuan dan kontrol dengan uji T-Independen.

\section{HASIL PENELITIAN}

1. Konsentrasi

Terdapat perbedaan rerata konsentrasi spermatozoa kelompok Kontrol $\left(\mathrm{P}_{0}\right)$ yang hanya diberi paparan asap rokok dibandingkan kelompok Perlakuan $\left(\mathrm{P}_{1}\right)$ dan 
Perlakuan $\left(\mathrm{P}_{2}\right)$ yang diberi paparan asap rokok dan ekstrak jintan hitam (Nigella sativa), dimana rerata konsentrasi spermatozoa kelompok perlakuan $\left(\mathrm{P}_{1}\right)$ dan $\left(\mathrm{P}_{2}\right)$ mengalami peningkatan dibandingkan dengan rerata konsentrasi spermatozoa kelompok kontrol dapat dilihat pada tabel 1.

Tabel 1. Rerata Konsentrasi Spermatozoa Tikus

\begin{tabular}{cc}
\hline Kelompok Sampel & $\begin{array}{c}\text { Rerata Konsentrasi } \\
\text { Spermatozoa (x10 }\end{array}$ \\
& ml) \\
\hline Kontrol $\left(\mathrm{P}_{0}\right)$ & \pm 42 \\
Perlakuan $\left(\mathrm{P}_{1}\right)$ & \pm 47 \\
Perlakuan $\left(\mathrm{P}_{2)}\right.$ & \pm 46 \\
\hline
\end{tabular}

Keterangan: Kelompol $\mathrm{P}_{0}$, kelompok pemaparan asap rokok, Kelompok $\mathrm{P}_{1}$, kelompok pemaparan asap rokok dan pemberian ekstrak jintan hitam (Nigella sativa) dengan dosis $2 \mathrm{mg}$, Kelompok $\mathrm{P}_{2}$, kelompok pemaparan asap rokok dan pemberian ekstrak jintan hitam (Nigella sativa) dengan dosis $3 \mathrm{mg}$.

\section{Motilitas}

Hasil pengamatan terhadap motilitas spermatozoa tikus wistar (Rattus norvegicus) dikategorikan dalam empat kelompok, yaitu kategori A spermatozoa yang bergerak cepat dan lurus ke depan, kategori B spermatozoa yang bergerak lambat kedepan atau berbelok-belok, kategori $\mathrm{C}$ bergerak di tempat, dan kategori D tidak bergerak. Berdasarkan kategori di atas didapatkan persentase motilitas spermatozoa normal dan abnormal, dimana kategori A dan B merupakan persentase motilitas spermatozoa normal sementara kategori C dan D merupakan persentase motilitas spermatozoa abnormal. Setelah dilakukan perlakuan, penilaian motilitas, dan pengelompokan data didapati hasil rerata persentase motilitas spermatozoa tikus wistar (Rattus norvegicus) dapat dilihat pada Tabel 2.
Tabel 2. Rerata Persentase Motilitas Spermatozoa Tikus Wistar (Rattus norvegicus)

\begin{tabular}{ccc}
\hline $\begin{array}{c}\text { Kelompok } \\
\text { Sampel }\end{array}$ & $\begin{array}{c}\text { Rerata } \\
\text { Motilitas } \\
\text { Normal } \\
(\%)\end{array}$ & $\begin{array}{c}\text { Rerata } \\
\text { Motilitas } \\
\text { Abnormal } \\
(\%)\end{array}$ \\
\hline Kontrol $\left(\mathrm{P}_{0}\right)$ & 20 & 80 \\
Perlakuan $\left(\mathrm{P}_{1}\right)$ & 67 & 33 \\
Perlakuan $\left(\mathrm{P}_{2}\right)$ & 77 & 23 \\
\hline
\end{tabular}

3. Morfologi

Penilaian terhadap morfologi spermatozoa terbagi menjadi dua yaitu morfologi normal dan abnormal. Penilaian morfologi abnormal dapat dilihat dari abnormalitas kepala, abnormalitas leher dan abnormalitas ekor, dapat dilihat pada gambar 1. Hasil yang didapatkan mengenai morfologi spermatozoa pada penelitian ini dapat dilihat pada tabel 3 .

Gambar 1. Morfologi Spermatozoa

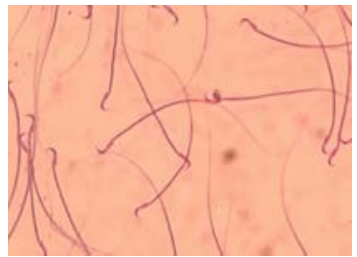

(a)

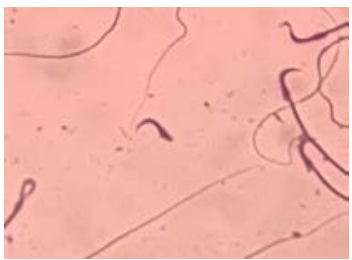

(c)

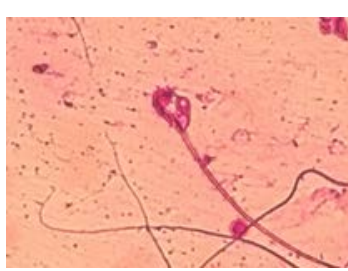

(b)

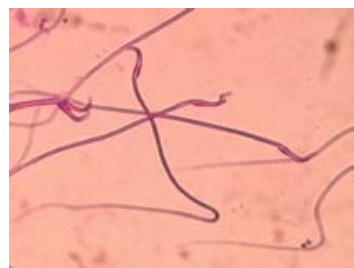

(d)
Keterangan: (a) morfologi spermatozoa normal (b) abnormalitas kepala (c) abnormalitas leher (d) abnormalitas ekor.

Tabel 3. Rerata Persentase Morfologi Spermatozoa Tikus

\begin{tabular}{ccc}
\hline $\begin{array}{c}\text { Kelompok } \\
\text { Sampel }\end{array}$ & $\begin{array}{c}\text { Rerata } \\
\text { Morfologi } \\
\text { Normal (\%) }\end{array}$ & $\begin{array}{c}\text { Rerata } \\
\text { Morfologi } \\
\text { Abnormal } \\
(\%)\end{array}$ \\
\hline Kontrol $\left(\mathrm{P}_{0}\right)$ & 37 & 63 \\
Perlakuan $\left(\mathrm{P}_{1}\right)$ & 74 & 26 \\
Perlakuan $\left(\mathrm{P}_{2}\right)$ & 89 & 11 \\
\hline
\end{tabular}


4. Uji Komparabilitas

Uji komparabilitas membandingkan rerata kualitas spermatozoa yaitu konsentrasi spermatozoa, motilitas spermatozoa, dan morfologi spermatozoa antar kelompok penelitian. Berdasarkan hasil uji normalitas dan homogenitas, data berdistribusi normal dan homogen, maka analisis komparatif yang digunakan adalah Uji-T Independen dan dapat dilihat pada tabel 4.

Tabel 4. Perbandingan Kualitas Spermatozoa

\begin{tabular}{ccc}
\hline Kualitas & $\begin{array}{c}\mathrm{P}_{0} \text { terhadap } \\
\mathrm{P}_{1} \\
(\mathrm{P}=)\end{array}$ & $\begin{array}{c}\mathrm{P}_{0} \text { terhadap } \\
\mathrm{P}_{2} \\
(\mathrm{P}=)\end{array}$ \\
\hline Konsmatozoa & 0,295 & 0,362 \\
Motilitas & 0,006 & 0,001 \\
$\begin{array}{c}\text { Normal } \\
\text { Motilitas }\end{array}$ & 0,006 & 0,001 \\
Abnormal & & \\
Morfologi & 0,000 & 0,000 \\
Normal & & \\
Morfologi & 0,000 & 0,000 \\
Abnormal & 0,
\end{tabular}

\section{BAHASAN}

Hasil analisis kualitas sperma yang dilakukan pada tikus wistar (Rattus norvegicus) yang terpapar asap rokok dan diberi ekstrak jintan hitam (Nigella sativa) menunjukan bahwa terjadi perbedaan bermakna dari motilitas dan morfologi spermatozoa tikus kelompok kontrol dan perlakuan, serta peningkatan yang nyata dari rerata konsentrasi spermatozoa tikus perlakuan dibandingkan kontrol. Peningkatan kualitas spermatozoa yang dipapar asap rokok tersebut dapat disimpulkan disebabkan oleh pemberian ekstrak jintan hitam (Nigella sativa) secara oral.

Penurunan kualitas spermatozoa yang ditemukan dalam percobaan ini dapat disebabkan oleh pemaparan rokok, sedangkan peningkatan kualitas spermatozoa yang terjadi dapat disebabkan oleh pemberian ekstrak jintan hitam (Nigella sativa). Rokok dapat menyebabkan penurunan dari konsentrasi, motilitas, dan kerusakan morfologi spermatozoa.6, 7, 8, 9
Penururan kualitas spermatozoa ini disebabkan oleh stress oksidatif yang diakibatkan adanya peningkatan ROS dari asap rokok yang akan menyebabkan kerusakan DNA dan akhirnya menyebabkan apoptosis spermatozoa sehingga akan terjadi penurunan kualitas spermatozoa.5, 9. Peningkatan yang ditemukan baik dari konsentrasi, motilitas, dan morfologi sejalan dengan penelitian sebelumnya yang menyimpulkan bahwa peningkatan tersebut dapat disebabkan oleh thymoquinon yang merupakan kandungan aktif utama dalam jintan hitam dan berperan sebagai superoxside anion scavenger yang dapat menyeimbangkan radikal bebas. ${ }^{5}$, 10 . Thymoquinon adalah antioksidan yang selanjutnya dapat mencegah terjadinya kerusakan DNA pada spermatozoa sehingga terjadi perbaikan kualitas spermatozoa. ${ }^{5}$

\section{Konsentrasi}

Pada tabel 1 tedapat peningkatan rerata konsentrasi spermatozoa dari tikus yang diberi jintan hitam (Nigella sativa) dibandingkan kontrol. Kelompok yang diberi ekstrak rerata konsentrasi spermatozoanya sebanyak $\left(\mathrm{P}_{1}\right) \pm 47 \times 10^{6}$ spermatozoa / $\mathrm{ml}$ dan $\left(\mathrm{P}_{2}\right) \pm 46 \times 10^{6}$ spermatozoa / $\mathrm{ml}$ dibandingkan dengan kelompok kontrol sebanyak $\pm 42 \times 10^{6}$ spermatozoa / ml.

Walaupun terdapat perbedaan antar kelompok perlakuan namun hasil analisa statistik menunjukan hasil yang tidak bermakna. ( $\mathrm{P}>0,05)$ Hal ini dapat disebabkan oleh perbedaan volume spermatozoa yang diperoleh atau volume larutan yang digunakan.

\section{Motilitas}

Pada tabel 2 terdapat penurunan rerata persentase spermatozoa motil di kelompok kontrol dibandingkan dengan kelompok perlakuan. Kelompok kontrol memiliki rerata motilitas spermatozoa normal sebanyak 20\%, kelompok Perlakuan $\left(\mathrm{P}_{1}\right)$ 67\%, dan kelompok Perlakuan $\left(\mathrm{P}_{2}\right)$ 77\%. Hal ini berarti pada kelompok kontrol hanya 20\% spermatozoa yang mempunyai 
daya tembus untuk dapat terjadi pembuahan sel telur.

Pada uji statistik perbandingan antara kelompok kontrol $\left(\mathrm{P}_{0}\right)$ dengan Perlakuan $\left(\mathrm{P}_{1}\right)$ ataupun kelompok kontrol $\left(\mathrm{P}_{0}\right)$ dengan Perlakuan $\left(\mathrm{P}_{2}\right)$ terdapat perbedaan yang bermakna $(\mathrm{P}<0,05)$. Hal ini sejalan dengan penelitian sebelumnya yang menunjukan perbaikan bermakna pada motilitas spermatozoa dan persentase sperma hidup kelompok percobaan yang diberi terapi jintan hitam (Nigella sativa). 11

\section{Morfologi}

Pada tabel 3 kelompok kontrol memiliki rerata morfologi normal terkecil sebesar 37\%, kelompok perlakuan $\left(\mathrm{P}_{2}\right)$ memiliki rerata morfologi normal terbanyak sebesar $89 \%$ dan kelompok perlakuan $\left(\mathrm{P}_{1}\right)$ sebesar $74 \%$. Hal ini menunjukan perbaikan morfologi yang signifikan jika ditinjau dari persentase rerata masing-masing perlakuan. Perlakuan $\left(\mathrm{P}_{2}\right)$ dengan dosis yang lebih banyak memiliki rerata persentase morfologi normal yang lebih baik dibangdingkan perlakuan $\left(\mathrm{P}_{1}\right)$.

Pada uji statistik ditemukan hasil yang bermakna $(\mathrm{P}<0,05)$ pada perbandingan kontrol dan perlakuan $\left(\mathrm{P}_{1}\right)$ serta kontrol dan perlakuan $\left(\mathrm{P}_{2}\right)$. Hal ini sesuai dengan temuan dari penelitian serupa yang pernah dilakukan, dimana perbaikan morfologi signifikan pada perlakuan dengan terapi ekstrak jintan hitam (Nigella sativa).

\section{SIMPULAN}

1. Terjadi perbedaan kualitas spermatozoa pada kelompok yang hanya terpapar asap rokok tanpa intervensi lainnya dan kelompok yang terpapar asap rokok dan diberi ekstrak jintan hitam (Nigella sativa).

2. Ekstrak jintan hitam (Nigella sativa) dapat memperbaiki kualitias spermatozoa.

\section{SARAN}

1. Penelitian lanjut dibutuhkan dengan jumlah sampel yang lebih banyak.

2. Perlu dilakukan penelitian lebih lanjut mengenai kandungan jintan hitam (Nigella sativa) lain yang dapat memperbaiki kualitas spermatozoa yang mengalami stress oksidatif.

3. Perlu dilakukan penelitian mengenai dosis maksimum pemberian jintan hitam (Nigella sativa).

4. Perlu dilakukan penelitian lebih lanjut mengenai faktor-faktor lain yang dapat menyebabkan stress oksidatif.

\section{DAFTAR PUSTAKA}

1. Hui Dai Lee, Hyo Serk Lee, Joong Shik Lee, Yong-Seog Park, Ju Tae Seo. Do Cigarette Smoking and Obesity Affect Semen Abnormality in Idiopathic Infertile Males. World J Mens Health Vol. 32, No. 2, 2014: 105-09.

2. Sara C H, Geoffrey $\mathbf{T}$ F. Gender empowerment and female-to-male smoking prevalence ratios. Bull World Health Organ 2011; 89: 195202.

3. Mujahidatul $M$, Rifki $M$, Noor $W$. Pengaruh Minyak Nigella sativa terhadap Kualitas Spermatozoa Tikus Wistar yang Terpapar Asap Rokok. J Indon Med Assoc, Volum: 62, Nomor: 5, 2012: 178-82.

4. Sunil K, Shiva M, V.V. Mishra, A.K. Gautam. Environmental \& lifestyle factors in deterioration of male reproductive health. Indian J Med Res 140 (Supplement), 2014, pp 29-35.

5. Ng Cho Ping, Noor Hashida Hashim, and Durriyyah Sharifah Hasan Adli. Effects of Nigella sativa (Habbatus sauda) Oil and Nicotine Chronic Treatments on Sperm Parameters and Testis Histological Features of Rats. Evidence-Based Complementary and Alternative Medicine. 2014: 1-7.

6. J R Kovac. A Khanna. L I Lipshultz. The effects of cigarette smoking on male fertility. Postgrad Med, 2015; 127(3): 338-41.

7. R Davar, L Sekhavat, and N Naserzadeh. Semen parameters of non-infertile smoker and non-smoker men. Journal of Medicine and Life. 2012;5(4):465468.

8. The Practice Committee of the American Society for Reproductive Medicine . 
Smoking and infertility: a committee opinion. Fertility and Sterility Vol. 98, No. 6, 2012; pp. 1400-1406.

9. Jason R. K., Abhinav K. \& Larry I. L. The effects of cigarette smoking on male fertility. Postgrad Med, 2015; 127(3): 338-341.

10.S. S. Elshama, G. M. G. Shehab, A E. ElKenawy, H. E. H. Osman, M. M. Farag. Role of Nigella Sativa Seeds on modulation testicular toxicity of colchicine repeated use in adult albino rats. Life Science Journal 10(4),2013;1629-1639.

11.M. Musfiroh, S Gustari. Pengaruh Pemberian Minyak Jintan Hitam (Nigella sativa L.) Terhadap Peningkatan Spermatogenesis Tikus Wistar Yang Terpapar Asap Rokok. Jurnal Kedokteran Hewan. Vol. 9 No. 2, 2015; 114-116. 